\title{
Soil Fertility in Two Shifting Cultivation Mayan Systems of Yucatan, Mexico
}

\section{Jorge H. Ramírez-Silva1* ${ }^{*}$ Genovevo Ramírez-Jaramillo', Mónica Guadalupe Lozano-Contreras ${ }^{2}$, Alejandro Cano-González ${ }^{1}$, Fernando Arellano-Martín ${ }^{3}$}

${ }^{1}$ Centro de Investigación Regional Sureste del Instituto Nacional de Investigaciones Forestales, Agrícolas y Pecuarias (INIFAP), Mérida, México

${ }^{2}$ Campo Experimental Mococha del Instituto Nacional de Investigaciones Forestales, Agrícolas y Pecuarias (INIFAP), Chetumal, México

${ }^{3}$ Campo Experimental Chetumal del Instituto Nacional de Investigaciones Forestales, Agrícolas y Pecuarias (INIFAP), Chetumal, México

Email: *ramirez.jorge@inifap.gob.mx

How to cite this paper: Ramírez-Silva, J.H., Ramírez-Jaramillo, G., Lozano-Contreras, M.G., Cano-González, A. and ArellanoMartín, F. (2021) Soil Fertility in Two Shifting Cultivation Mayan Systems of Yucatan, Mexico. Open Access Library Journal, 8: e7858.

https://doi.org/10.4236/oalib.1107858

Received: August 16, 2021

Accepted: October 11, 2021

Published: October 14, 2021

Copyright $\odot 2021$ by author(s) and Open Access Library Inc.

This work is licensed under the Creative Commons Attribution International License (CC BY 4.0).

http://creativecommons.org/licenses/by/4.0/

\begin{abstract}
The Slash and Burn (SB) System, practiced by the Mayan farmers of Yucatan, is one of the oldest forms of land use. After SB the soil is cultivated with corn by two or three consecutive years and then abandoned for a fallow period of 15 to 40 years to restore soil fertility when new vegetation is cut and burned again. There are contrasting points of view related to the advantages of SB on soil fertility. So, this work aimed to evaluate changes in the soil fertility of two Mayan farmers (Leoncio and Epitacio), practicing SB in five different agroecosystems of Yucatan, Mexico. Three soil subsamples, at $0-20 \mathrm{~cm}$ deep, were taken per each agroecosystem and mixed to form a composite sample to analyse: $\mathrm{pH}$, Organic Matter (OM), Nitrogen $(\mathrm{N})$ as Nitrates $\left(\mathrm{N}_{-} \mathrm{NO}_{3}\right)$, Available Phosphorus (P), Potassium $\left(\mathrm{K}^{+}\right)$, Calcium $\left(\mathrm{Ca}^{2+}\right)$, Magnesium $\left(\mathrm{Mg}^{2+}\right)$ and Zinc $\left(\mathrm{Zn}^{2+}\right)$. There was a general trend to increase $\mathrm{OM}, \mathrm{N}-\mathrm{NO}_{3}, \mathrm{P}, \mathrm{K}$ and $\mathrm{Mg}$ in SB of Leoncio but $\mathrm{Zn}$ decreased. In Epitacio's OM, P and $\mathrm{K}$ increased with SB. Long fallow periods showed the lowest $\mathrm{pH}$ values while the highest ones in the SB showed the influence of ashes. All agroecosystems showed High and Very High contents of OM although the contents of $\mathrm{N}-\mathrm{NO}_{3}$ and $\mathrm{P}$ were Low, except the Very High content of $\mathrm{N}^{-\mathrm{NO}_{3}}$ in the Agroecosystem 3 of Epitacio in the rendzic Leptosol ( $r z L P$ ). In all agroecosystems $\mathrm{K}$ and $\mathrm{Ca}$ were High whilst $\mathrm{Mg}$ was Medium. The overall average $\mathrm{Zn}$ content in Leoncio's was Lower $(0.38 \mathrm{ppm})$ than Epitacio's ecosystem $(2.76 \mathrm{ppm})$. A rendzic Leptosol showed extreme higher contents of all nutrients than the red Cambisol.
\end{abstract}




\section{Subject Areas}

Agricultural Engineering-Environmental Sciences

\section{Keywords}

Nutrients, Heterogeneity, Critical Levels, Chac Lu' um, Pus Lu’ um

\section{Introduction}

At the end of the 1970's deforestation rates for the humid tropics were estimated to be 6.9 million hectares per year [1] and doubled to 14.8 million in 1991 [2]. The number of people who depend on shifting cultivation, practicing Slash and Burn (SB), for their livelihoods has been estimated at about 250 to 300 million [3] [4].

SB system is mainly to establish subsistence crops, it is not a primitive or incipient cultivation method but a specialized technic one, which has evolved in response to specific climatological and soil conditions in the tropical lowlands [5]. However, it has been reported [6] that the world was losing about half of its forests to agriculture and other uses, and the remaining were heavily altered. About 72 percent of the original 1450 million hectares of tropical forests have been converted to other uses [7] [8].

In Yucatan Mexico, corn production continues to be carried out mainly under rainfed conditions in approximately 130 thousand hectares and 90 percent is being produced under SB cultivation. This is an ancient Mayan production system so-called Mayan Milpa (MM) involving different activities [9] and since the 70 's, considerable efforts were made to understand why Mayan peasants were facing important corn yield reduction in the MM [10].

MM based on SB is considered a locally managed system that alters the ecosystem less than other modern agricultural production ones [11]. Professor Hernández Xolocotzi commented that MM is an efficient system that takes advantage of the forest resources and it is adaptable to the Calcareous soils of Yucatan [12] but its productive capacity can be maintained just if the land is to be rested for a minimum of 7 years until the forest is regenerated. Soil fertility is related to the litter accumulation, nutrients circulation and fallow periods. The Organic Matter (OM) and nutrients are incorporated through the ashes [13].

In the MM the fallow periods have been reduced from 20 to 7 years and soil fertility has decreased, being the basic regulator of the agroecosystem and the grade of competition between weeds and crops is mainly an adaptation to the low soil fertility [14].

The problem being faced is the use of fire, provoking a decrease in the initial values of Organic Matter (OM) when temperatures are above $450^{\circ} \mathrm{C}$. Some other works suggest that in low intensity fires the effect is the opposite when ashes are accumulated on the soil [15]. Fire can also alter the OM quality when acting as 
an agent that accelerates mineralization rates and in the post-fire decomposition, the humus is more resistant to microbial degradation [16] [17].

On the other hand, burning increases mineralization of organic forms of nitrogen, but volatilization losses result in a negative balance for this element [18] and the higher amount of $\mathrm{P}$, after burning, can be explained by the increase in soil temperature, favoring organic P mineralization [19] and releasing the phosphates occluded in the soil aggregates [20].

Due to the uncertainty about the advantages of the SB system, this work aimed to better elucidate the fertility changes that soils undergo when they are subjected to different fallow periods and uses in the MM where SB is being practiced.

\section{Materials and Methods}

\subsection{Location and Agroecosystems Studied}

The study was carried out in calcareous karstic soils of a Mayan community of Nuevo Tezoco, municipality of Tizimin in the state of Yucatan, located at: $21^{\circ} 18^{\prime} 24.94^{\prime \prime}$ North Latitude and $87^{\circ} 33^{\prime} 42.00^{\prime \prime}$ West Longitude with a height of 13 meters above sea level with an $\mathrm{Aw}_{2}$ climate [21].

Two Mayan systems were selected. Leoncio Loria Chimal (System 1) and Epitacio Ku Puc (System 2) being the representative farmers of the MM who have been managing the forest with multi-crops forming different agroecosystems. The MM is being practiced in red soils (Cambisols) located in the low part of the landscape associated with black soils with loose stones (rendzic Leptosols) in the upper part of the landscape (Figure 1). Both soils are classified as Chac Lu' um and Pus Lu' um respectevely in Mayan terminology [22] [23] [24].

In Table 1 are described the 5 agroecosystems, under shifting cultivation, per each farmer. The agroecosystems consisted on forests with fallow periods of 30 and 5 years (Leoncio 1 and 2) and 10 years (Epitacio 1 ) and the other ones with

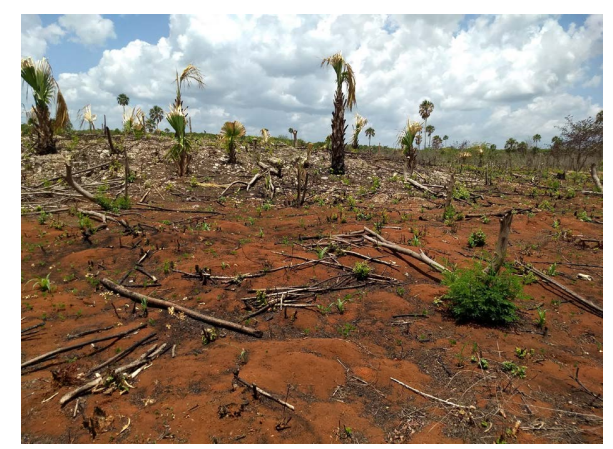

(a)

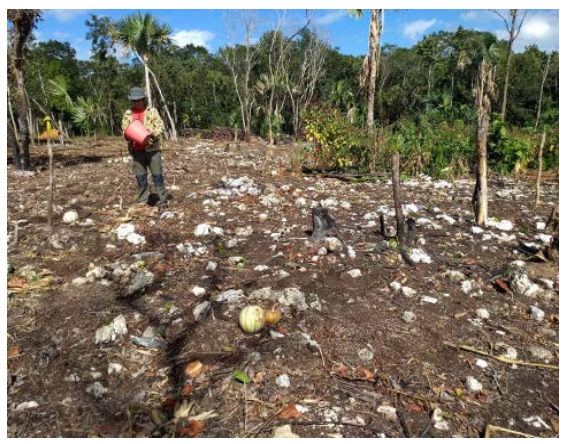

(b)

Figure 1. Natural and common association of a typical Cambisol-Chak Lu' um (Red soil in the low position of the landscape) and a typical rendzic Leptosol-Pus Lu' um (Black soil with loose stones in the upper position of the landscape) where Slash and Burn has been practiced in the studied area. (a) Red Cambisol in Yucatan with SB; (b) rendzic Leptosol in Yucatan with SB. 
Table 1. Mayan Agroecosystems studied in the Maya community of Nuevo Tezoco, Municipality of Tizimin, Mexico.

\begin{tabular}{|c|c|c|c|}
\hline Farmer & $\begin{array}{l}\text { Agroecosystem } \\
\left(\mathrm{N}^{\circ}\right)\end{array}$ & Soil & Description \\
\hline \multirow{5}{*}{$\begin{array}{l}\text { Leoncio Loria } \\
\text { Chimal }\end{array}$} & 1 & Red-CM & 30 years old forest \\
\hline & 2 & Red-CM & 5 years old forest \\
\hline & 3 & Red-CM & $\begin{array}{l}\text { Recent SB, cultivated with corn, after clearing a } \\
5 \text { years old forest }\end{array}$ \\
\hline & 4 & Red-CM & $\begin{array}{l}3 \text { consecutive years planted with corn after SB } \\
\text { a } 5 \text { years old forest }\end{array}$ \\
\hline & 5 & Red-CM & $\begin{array}{c}3 \text { consecutive years planted with fruit trees } \\
\text { intercropped with corn after SB a } 5 \text { years old } \\
\text { forest }\end{array}$ \\
\hline \multirow{5}{*}{ Epitacio Ku Puc } & 1 & Red-CM & 10 years old forest \\
\hline & 2 & Red-CM & $\begin{array}{c}\text { Recent SB, cultivated with maize, after SB a } 10 \\
\text { years old forest }\end{array}$ \\
\hline & 3 & Black-rz LP & $\begin{array}{l}\text { Recent SB, cultivated with maize, after SB a } 10 \\
\text { years old forest }\end{array}$ \\
\hline & 4 & Red-CM & $\begin{array}{l}\text { Intercropped fruit trees, corn and beans in a } \\
\text { soil previously cultivated with tropical grasses } \\
\text { after SB a } 10 \text { years old forest }\end{array}$ \\
\hline & 5 & Red-CM & $\begin{array}{c}8 \text { continuous years cultivated with corn after } \\
\text { SB a } 25 \text { years old forest }\end{array}$ \\
\hline
\end{tabular}

different cropping systems. All agroecosystems are on red Cambisols (CM) except Epitacio's Agroecosystem 3 resting on a rendzic Leptosol (rz LP). The agroecosystems were separated for no more than 100 meters each other and soil samples were taken randomly.

\subsection{Soil Sampling and Chemical Analytical Tests for Nutrients}

Three soil subsamples, at $0-20 \mathrm{~cm}$ deep, were taken per each agrecosystem and mixed until forming a composite sample in order to analyze: $\mathrm{pH}$, Organic Matter $(\mathrm{OM})$, Nitrogen as Nitrates $\left(\mathrm{N}-\mathrm{NO}_{3}\right)$, Assimilable Phosphorus (P), Potassium $\left(\mathrm{K}^{+}\right)$, Calcium $\left(\mathrm{Ca}^{2+}\right)$, Magnesium $\left(\mathrm{Mg}^{2+}\right)$ and $\mathrm{Zinc}\left(\mathrm{Zn}^{2+}\right)$ as a micronutrient.

The $\mathrm{pH}$ was measured with a potentiometer in a 1:1 soil:water ratio, the OM (\%) was determined by Walkley and Black, the $\mathrm{N}^{-\mathrm{NO}_{3}}$ (ppm) by the Brusina method, the P (ppm) by Bray method. K (meq/100gr), Ca (meq/100gr) and Mg (meq/100gr) were extracted with Ammonium Acetate $\mathrm{pH} 7$ and $\mathrm{Zn}$ (ppm) with DTPA extraction [25].

\subsection{Reference Soil Values for Soil Fertility}

The reference critical levels, for comparison purposes, were taken from the Official Mexican Standard that establishes specifications for fertility, salinity and soil classification. Studies, sampling and analysis suggested (Table 2) by SEMARNAT (2002) [26]. 
Table 2. Reference levels of soil attributes suggested by SEMARNAT (2002) [26].

\begin{tabular}{cccc}
\hline \multirow{2}{*}{ Soil attributes } & \multicolumn{3}{c}{ Soil test reference } \\
\cline { 2 - 4 } & High & Medium & Low \\
\hline $\mathrm{OM}(\%)$ & $3.6-6.0$ & $1.6-3.5$ & $0.6-1.5$ \\
$\mathrm{~N}-\mathrm{NO}_{3}(\mathrm{ppm})$ & $40-60$ & $20-40$ & $10-20$ \\
$\mathrm{P}(\mathrm{ppm})$ & $>11.0$ & $5.5-11.0$ & $<5.5$ \\
$\mathrm{~K}(\mathrm{Cmol} / \mathrm{kilo})$ & $>0.6$ & $0.3-0.6$ & $0.2-0.3$ \\
$\mathrm{Ca}(\mathrm{Cmol} / \mathrm{kilo})$ & $>10.0$ & $5.0-10.0$ & $2.0-5.0$ \\
$\mathrm{Mg}(\mathrm{Cmol} / \mathrm{kilo})$ & $>30.0$ & $1.3-3.0$ & $0.5-1.3$ \\
$\mathrm{Zn}(\mathrm{ppm})$ & $>1.0$ & $0.5-1.0$ & $<0.5$ \\
\hline
\end{tabular}

All samples with lower contents than the Medium rate were graded as Deficient and those ones with higher values than the Medium Rate were considered as Sufficient or even in excess.

\subsection{Statistical Analysis}

Coefficient of Variation (CV) to all soil attributes, per each farm system, were calculated as well as the Coefficient of Correlation (r) and Determination $\left(R^{2}\right)$ to measure the grade of relationship between soil attributes.

The CV was expressed as a percentage (\%) resulted of dividing the standard deviation (Sd) of a sample by the arithmetic mean [27]. The higher the CV value the greater the heterogeneity of the soil attribute; and the lower the CV the greater the homogeneity. Normally, in agricultural field trials, CV's are considered low when they are less than $10 \%$; medium from $10 \%$ to $20 \%$, high from $20 \%$ to $30 \%$ and very high above $30 \%$ [28].

When CV's are lower than or equal to $30 \%$ the data set is "Homogeneous" and when exceeding 30\%, it is "Heterogeneous". Muñoz et al., (2006) [29] reported CV values of $20 \%$ to $40 \%$ as Medium and less than $10 \%$ as Low variability.

The $r$ measured the linear dependence between two quantitative random variables (dependent-y and independent-x) and was considered as an index to measure the degree of relationship between two soil attributes.

The $\mathrm{R}^{2}$ quantified the proportion (\%) of the total values of the dependent- $y$ soil attribute which can be explained by changes on the independent- $x$ soil variable. It can range between 0 and $1(0 \%-100 \%)$. An $R^{2}$ closer to $1(100 \%)$ means a tight relationship between two soil properties.

\section{Results and Discussion}

\subsection{Soil Reaction (pH)}

The $\mathrm{pH}$ of the studied agroecosystems, according to Phytomonitor Labs, (2020) [25] ranged from 6.85 to 7.64 (Table 3) with a general mean of 7.17 and 7.31 for Leoncio and Epitacio systems respectively. Agroecosystems numbered 1 with 
Table 3. Grade of alkalinity, indicated by the soil $\mathrm{pH}$ in different agroecosystems of the two shifting cultivation Mayan System in Nuevo Tezoco, Municipality of Yucatan, Mexico.

\begin{tabular}{cccc}
\hline Farmer & Agroecosystem $\left(\mathbf{N}^{*}\right)$ & Soil pH & Grade \\
\hline \multirow{2}{*}{ Leoncio Loria Chimal } & 1 & 6.85 & Neutral \\
& 2 & 7.05 & Neutral \\
& 3 & 7.36 & Neutral \\
& 5 & 7.15 & Neutral \\
& Average & 7.46 & Fairly Alkaline \\
& Sd & 7.17 & Neutral \\
CV (\%) & 0.22 & Very Low \\
\hline Epitacio Ku Puc & 3.04 & Neutral \\
& 3 & 6.93 & Fairly Alkaline \\
& 4 & 7.38 & Fairly Alkaline \\
& 5 & 7.64 & Neutral \\
& Average & 7.33 & Neutral \\
Sd & 7.28 & Neutral \\
CV (\%) & 7.31 & Very Low \\
\hline
\end{tabular}

long fallow periods, corresponding to the 30 (Leoncio) and 10 (Epitacio) years old forests, showed the lowest values with 6.85 and 6.93 respectively. The other agroecosystems, where slash and burn has been practiced, had the highest $\mathrm{pH}$ values showing the influence of ashes accumulated during the shifting process.

The lowest $\mathrm{pH}$ may be related to the influence of OM decomposition during the fallow period and could be a function of the Nitrification process where four hydrogens $\left(4 \mathrm{H}^{+}\right)$are released from two Ammonium $\left(\mathrm{NH}_{4}^{+}\right)$molecules as Ortiz Villanueva [30] suggested.

On the other hand, the increment of $\mathrm{pH}$, toward alkalinity, could be due to the contributions of ashes after burning of vegetation. The ashes contain significant amounts of $\mathrm{P}, \mathrm{K}, \mathrm{Ca}$ and $\mathrm{Mg}$ as oxides, hydroxides and carbonates with alkaline effects in the soil [31]. Soil $\mathrm{pH}$ is one of the chemical properties more affected by fire. The remaining ashes contain large amounts of potassium carbonate $\left(\mathrm{CO}_{3} \mathrm{~K}_{2}\right)$ with a basic (high alkalinity) reaction when it is hydrolyzed [15].

On the other hand, the soil $\mathrm{pH}$ among agroecosystems, for both Leoncio and Epitacio systems, were highly homogeneous as it was shown by the very low CV's with 3.04 and $3.12 \%$ respectively.

\subsection{Soil Organic Matter and Primary Essential Nutrients $(N, P, K)$ under Shifting Cultivation Systems}

\subsubsection{Organic Matter (OM) and Nitrogen $\left(\mathrm{N}-\mathrm{NO}_{3}\right)$}

Very high OM contents were found in all ecosystems (Table 4), with an overall 
Table 4. Changes in soil $O M$ and primary essential nutrients $(N-P-K)$ at $0-20 \mathrm{~cm}$ deep in different agroecosystems of two Maya farmers practicing slash and burn cultivation.

\begin{tabular}{|c|c|c|c|c|c|}
\hline Farmer & $\begin{array}{l}\text { Agroecosystem } \\
\left(\mathrm{N}^{\circ}\right)\end{array}$ & $\begin{array}{l}\text { OM } \\
(\%)\end{array}$ & $\begin{array}{l}\mathrm{N}-\mathrm{NO}_{3} \\
(\mathrm{ppm})\end{array}$ & $\begin{array}{c}\mathrm{P} \\
(\mathrm{ppm})\end{array}$ & $\begin{array}{c}\mathrm{K} \\
\left(\mathrm{Cmol} \cdot \mathrm{kg}^{-1}\right)\end{array}$ \\
\hline \multirow{8}{*}{$\begin{array}{c}\text { Leoncio Loria } \\
\text { Chimal }\end{array}$} & 1 & $4.42(\mathrm{H})$ & $12.00(\mathrm{~L})$ & $6.00(\mathrm{~L})$ & $0.56(\mathrm{H})$ \\
\hline & 2 & $5.70(\mathrm{H})$ & $13.60(\mathrm{~L})$ & $4.00(\mathrm{~L})$ & $0.84(\mathrm{H})$ \\
\hline & 3 & $4.36(\mathrm{H})$ & $28.00(\mathrm{~L})$ & $8.00(\mathrm{~L})$ & $1.02(\mathrm{H})$ \\
\hline & 4 & $4.02(\mathrm{H})$ & $19.20(\mathrm{~L})$ & $8.00(\mathrm{~L})$ & $1.10(\mathrm{H})$ \\
\hline & 5 & $3.08(\mathrm{H})$ & $18.40(\mathrm{~L})$ & $8.00(\mathrm{~L})$ & $1.33(\mathrm{H})$ \\
\hline & Average & $4.31(\mathrm{H})$ & $18.24(\mathrm{~L})$ & $6.80(\mathrm{~L})$ & $0.96(\mathrm{H})$ \\
\hline & Sd & 0.84 & 5.60 & 1.6 & 0.46 \\
\hline & $\mathrm{CV}$ & $19.51(\mathrm{M})$ & $30.69(\mathrm{VH})$ & $23.53(\mathrm{H})$ & $48.19(\mathrm{VH})$ \\
\hline \multirow{9}{*}{ Epitacio Ku Puc } & 1 & $5.16(\mathrm{H})$ & $14.40(\mathrm{~L})$ & $8.00(\mathrm{~L})$ & $0.84(\mathrm{H})$ \\
\hline & 2 & $3.75(\mathrm{H})$ & $17.60(\mathrm{~L})$ & $2.00(\mathrm{~L})$ & $1.18(\mathrm{H})$ \\
\hline & 3 & $19.43(\mathrm{VH})$ & $111.80(\mathrm{VH})$ & $12.00(\mathrm{~L})$ & $1.28(\mathrm{H})$ \\
\hline & 4 & $26.13(\mathrm{VH})$ & $16.00(\mathrm{~L})$ & $6.00(\mathrm{~L})$ & $0.82(\mathrm{M})$ \\
\hline & 5 & $17.768(\mathrm{VH})$ & $17.60(\mathrm{~L})$ & $10.00(\mathrm{~L})$ & $1.38(\mathrm{H})$ \\
\hline & Average & $14.46(\mathrm{VH})$ & $35.48(\mathrm{M})$ & $7.60(\mathrm{~L})$ & $1.1(\mathrm{H})$ \\
\hline & Sd & 8.64 & 38.18 & 3.44 & 0.23 \\
\hline & $\mathrm{CV}$ & $59.79(\mathrm{VH})$ & $107.61(\mathrm{VH})$ & $45.28(\mathrm{VH})$ & $20.86(\mathrm{M})$ \\
\hline & Critical Limits & $1.6-3.5$ & $20-40$ & $20-30$ & $0.3-0.6$ \\
\hline
\end{tabular}

Note: $\mathrm{H}=$ High, $\mathrm{M}=$ Medium, $\mathrm{L}=$ Low.

average of $4.3 \%$ for Leoncio and an excesive very high OM value of $14.46 \%$ for Epitacio. The critical limits reported by the Official Mexican Standard are from 2.5 to $3.0 \%$ [26].

The influence of the fallow period on the OM is noted in the Leoncio ecosystems where the highest OM contents were found in the 30 and 5 years old forests with 4.42 and $5.70 \%$ respectively. Similar values (5.36\%) were found by Medina et al. [32] in an over 30 years old forest in Campeche Mexico.

On the other hand, the ecosystem 5 of Leoncio, referred to a 3 years of fruit trees and corn, after clearing a 5 years old forest, obtained the lowest OM content with 3.08\%; This is also in agreement with Medina et al., (2017) [32] who reported that in soils cultivated with mango ( 1 to 5 years) the OM content was $3.26 \%$.

It is remarkable the behaviour of the ecosystems 3, 4 and 5 of Epitacio where excessive amount of OM was found with 19.43, 26.13 and 17.76\%. The first value is related to the thin black soil classified as rendzic Leptosol (Pus Luum) located in the upper part of the landscape with loose stones, where corn was sown in the spring-summer cycle after a 10 years old forest was slashed and burned. The second highest value $(26.13 \%)$ is for an ecosystem in red soils (Cambisol) cur- 
rently cultivated with fruit trees in substitution of tropical grasses after slashing and burning a 10 years old vegetation. The third value (17.76) refers to a red soil with 8 consecutive years of use after burning a 25 years old forest.

Regarding to the available inorganic nitrogen $\left(\mathrm{N}-\mathrm{NO}_{3}\right)$, it could be observed that despite of the high and excessive $\mathrm{OM}$, most ecosystems showed $\mathrm{N}-\mathrm{NO}_{3}$ contents below the critical level, except for ecosystem 3 of Leoncio with 28 ppm and Ecosystem 3 of Epitacio with 111.8 ppm. The agroecosystems 3, 4 and 5 of Leoncio (recently slashed and burned) also showed higher important values of $\mathrm{N}-\mathrm{NO}_{3}$ than agroecosystems 2 and 3 (30 and five years old forests).

The low relationship between $\mathrm{OM}$ and $\mathrm{N}-\mathrm{NO}_{3}$ can be based on the quality of the OM prevailing in each ecosystem studied and this has to do with the $\mathrm{C} / \mathrm{N}$ Ratio, which is a quality index. High values imply that the organic matter decomposes slowly because the microorganisms immobilize the nitrogen for plant tissues decomposition. The few amount of $\mathrm{N}^{-\mathrm{NO}_{3}}$ released to the soil solution could have been lost by leaching to deep soil horizons due to high infiltration rates. The karst of the state of Yucatan is of the holokarst type, where water is drained to the subsoil [33].

Ecosystem 4 of Epitacio, previously managed with grasses, obtained the highest $\mathrm{OM}$ content with $26.13 \%$. However, the amount of $\mathrm{N}^{-\mathrm{NO}_{3}}(16 \mathrm{ppm})$ is below the critical range of $20-40 \mathrm{ppm}$. This may be due to the fact that the remaining roots of grasses, with high lignin, have a high Carbon/Nitrogen ratio $(\mathrm{C} / \mathrm{N})$ so microorganisms faced very strong difficulties to mineralize the OM.

The extreme exception was Ecosystem 3 of Epitacio since very high amounts of $\mathrm{N}-\mathrm{NO}_{3}(111.8 \mathrm{ppm})$ were found. However, the productivity of the stony soil can drastically decrease due to the very restricted area for root development in a shallow thin soil.

The variability of the soil $\mathrm{OM}$ and $\mathrm{N}-\mathrm{NO}_{3}$ depended on the management and conditions of both production systems. The CV of OM in Leoncio was lower than that in Epitacio, graded as Medium (19.51\%) and Very High (59.79\%) heterogeneity respectively. In the case of $\mathrm{N}^{-\mathrm{NO}_{3}}$ the heterogeneity was Very High for both systems although for Epitacio the CV was extremely high with $107.61 \%$. This very high heterogeneity is given by the extreme high content of $\mathrm{N}-\mathrm{NO}_{3}$ in the agroecosystem 3 . Eliminating the extreme value, the CV would only be $8 \%$.

Unlike other ecosystems, nitrogen mineralization in arid and semi-arid ecosystems occurs in patches, in a heterogeneous way, in response to microclimate conditions and contribution of organic matter. Soil fertility is distributed in island depending on the presence and abundance of the vegetation. $\mathrm{N}$ mineralization values are higher under the trees and shrubs canopies than the adjacent open spaces [34].

\subsubsection{Available Phosphorus (P)}

The $\mathrm{P}$ contents in all ecosystems were well below the critical limits of 20 - 30 $\mathrm{ppm}$. The lowest values were found in the ecosystems 2 of Leoncio and Epitacio with 4.0 and $2.0 \mathrm{ppm}$ respectively, corresponding to a 30 and 5 years old forest. 
Even the ecosystem 3 of Epitacio, with the highest P content (12 ppm), did not reach the optimum range of $\mathrm{P}(20-40 \mathrm{ppm})$ being $40 \%$ below the minimum value (20 ppm) of the critical level.

The foregoing can be related to the calcareous origin of the Yucatan Peninsula where insoluble precipitates such as dicalcium and tricalcium phosphates can be formed, converting P into a non-available nutrient by the plants [35]. However, there was a general trend of increasing $\mathrm{P}$ in those $\mathrm{SB}$ agroecosystems.

Inclusion of $\mathrm{P}$, in a strategic plan for proper management of inorganic and organic fertilizers is fundamental. It has to be considered the heterogeneous spatial distribution of P since CV's ranged from High (Leoncio) to Very High (Epitacio).

\subsubsection{Available Potassium $(K)$}

Potassium (K) like Nitrogen $(\mathrm{N})$ and Phosphorous (P) is a primary essential element required in large quantities depending on the crop. Studies carried out in Yucatán have confirmed that the amounts of exchangeable $\mathrm{K}$ in soils are well above than the sufficiency range of 100 to $250 \mathrm{ppm}$. This is also manifested in the ecosystems of the MM where $\mathrm{K}$ were in excess; mainly in those ecosystems most recently slashed and burned.

The highest $\mathrm{K}$ contents are referred to ecosystems 5 of Leoncio and Epitacio with 1.33 and $1.38 \mathrm{Cmol} \cdot \mathrm{kg}^{-1}$ respectively. Both ecosystems corresponded to a surface where slash and burn was practiced 3 and 8 years ago; the former with a 5 years old vegetation and the later with a 25 years old one. This must be related to the residual effect and contribution of ashes after burning the vegetation. All soils were well above the sufficiency range and only Agroecosystem 1 of Leoncio (30-year-old forest) was in a satisfactory normal range with $218 \mathrm{ppm}$.

\subsubsection{Calcium (Ca), Magnesium $(\mathrm{Mg})$ and Zinc $(\mathrm{Zn})$ in Soils under Shifting Cultivation}

In Table 5 are shown the $\mathrm{Ca}, \mathrm{Mg}$ and $\mathrm{Zn}$ contents in soils of the two different ecosystems studied. The general average of $\mathrm{Ca}$ was found to be 29.82 and 28.39 $\mathrm{Cmol} \cdot \mathrm{kg}^{-1}$ for Leoncio and Epitacio systems respectively, exceeding more than $190 \%$ the upper critical limit $\left(10.0 \mathrm{Cmol} \cdot \mathrm{kg}^{-1}\right)$ suggested in Table 2.

Remarkable extreme overall average values for $\mathrm{Ca}\left(71.0 \mathrm{Cmol} \cdot \mathrm{kg}^{-1}\right)$ and $\mathrm{Mg}$ (7.32 Cmol. $\mathrm{kg}^{-1}$ ) were found, again, in the ecosystem 3 of Epitacio. This is an area located in the upper part of the landscape with black soil and loose stones (rendzic LeptosoI) recently cultivated with maize after slashing and burning a 10 years old forest. This is the same agroecosystem with one of the highest content of $\mathrm{OM}$ as well as the highest $\mathrm{pH}, \mathrm{N}-\mathrm{NO}_{3}, \mathrm{P}$ and $\mathrm{K}$ values founded. Similar results have been reported by different authors [36].

Since all ecosystems exceeded the critical limits of Ca, phosphorus (P) could be a limiting nutrient for crops. Above $\mathrm{pH} 7$, Calcium forms complexes with phosphorus as Tricalcium Phosphate $\mathrm{Ca}_{3}\left(\mathrm{PO}_{4}\right)_{2}$; which is a none available form of $\mathrm{P}$ to plants [37].

In the case of $\mathrm{Mg}$, the overall average for both Leoncio and Epitacio systems 
Table 5. Changes in secondary essential soil nutrients $(\mathrm{Ca}, \mathrm{Mg})$ and Zinc as a micronutrient at $0-20 \mathrm{~cm}$ deep in different agroecosystems of two Maya farmers practicing slash and burn cultivation.

\begin{tabular}{|c|c|c|c|c|}
\hline Farmer & $\begin{array}{l}\text { Agroecosystem } \\
\left(\mathrm{N}^{\circ}\right)\end{array}$ & $\mathrm{Ca}(\mathrm{meq} / 100 \mathrm{gr})$ & $\mathrm{Mg}$ (meq/100gr) & $\mathrm{Zn}(\mathrm{ppm})$ \\
\hline \multirow{8}{*}{$\begin{array}{c}\text { Leoncio Loria } \\
\text { Chimal }\end{array}$} & 1 & $35.60(\mathrm{H})$ & $2.63(\mathrm{M})$ & $0.40(\mathrm{~L})$ \\
\hline & 2 & $29.50(\mathrm{H})$ & $1.43(\mathrm{M})$ & $0.70(\mathrm{M})$ \\
\hline & 3 & $26.50(\mathrm{H})$ & $1.51(\mathrm{M})$ & $0.40(\mathrm{~L})$ \\
\hline & 4 & $34.00(\mathrm{H})$ & $2.47(\mathrm{M})$ & $0.40(\mathrm{~L})$ \\
\hline & 5 & $23.50(\mathrm{H})$ & $2.31(\mathrm{M})$ & $0.00(\mathrm{~L})$ \\
\hline & Average & $29.82(\mathrm{H})$ & $2.07(\mathrm{M})$ & $0.38(\mathrm{~L})$ \\
\hline & $\mathrm{Sd}$ & 4.52 & 0.50 & 0.22 \\
\hline & CV (\%) & $15.14(\mathrm{M})$ & $24.20(\mathrm{H})$ & $58.61(\mathrm{VH})$ \\
\hline \multirow{9}{*}{ Epitacio Ku Puc } & 1 & $25.00(\mathrm{H})$ & $2.95(\mathrm{M})$ & $1.00(\mathrm{M})$ \\
\hline & 2 & $24.00(\mathrm{H})$ & $2.39(\mathrm{M})$ & $0.80(\mathrm{M})$ \\
\hline & 3 & $71.00(\mathrm{H})$ & $7.32(\mathrm{H})$ & $10.20(\mathrm{H})$ \\
\hline & 4 & $24.00(\mathrm{H})$ & $2.15(\mathrm{M})$ & $0.90(\mathrm{M})$ \\
\hline & 5 & $26.50(\mathrm{H})$ & $2.87(\mathrm{M})$ & $0.90(\mathrm{M})$ \\
\hline & Average & $28.39(\mathrm{H})$ & $3.54(\mathrm{H})$ & $2.76(\mathrm{H})$ \\
\hline & Sd & 18.47 & 1.92 & 3.72 \\
\hline & $\mathrm{CV}$ & $65.07(\mathrm{VH})$ & $54.16(\mathrm{VH})$ & $134.80(\mathrm{VH})$ \\
\hline & Critical Limits & $5.0-10.0$ & $1.3-3.0$ & $0.5-1.0$ \\
\hline
\end{tabular}

Note: $\mathrm{H}=$ High, $\mathrm{M}=$ Medium, $\mathrm{L}=$ Low

were 2.07 and $3.54 \mathrm{Cmol} \cdot \mathrm{kg}^{-1}$; Leoncio being inside the optimum range of 1.3 $3.0 \mathrm{Cmol} \cdot \mathrm{kg}^{-1}$ and Epitacio a little bit higher. With the exception of the higher $\mathrm{Mg}$ content of the agroecosystem 3 of Epitacio all others were in the optimum range.

One third of the soils of the world are calcareous [38] with important microelements disorders like $\mathrm{Zinc}(\mathrm{Zn})$ due to high concentrations of carbonates $\left(\mathrm{CO}_{3}^{2-}\right)$ and (hidoxides) $\mathrm{OH}^{-}$. The availability of this element depends on the $\mathrm{pH}$ and decreases 100 times for each unit increase in $\mathrm{pH}$.

Corn is a highly Zinc-demanding crop and it is probable that more than the 396 thousand hectares planted with corn in the Yucatan Peninsula are being affected by $\mathrm{Zn}$ deficiencies [39]. This is the case of Leoncio where $\mathrm{Zn}$ deficiencies were found in all agroecosystems with an overall low average of $0.38 \mathrm{ppm}$ whilst Epitacio ranked High with $2.76 \mathrm{ppm}$.

With the exception of Agroecosystem 3 of Epitacio the others were qualified as Medium whilst for Leoncio the Agroecosystems showed to have Low $\mathrm{Zn}$ contents except Agro ecosystem 2 with Medium content. The High general mean $\mathrm{Zn}$ value in Epitacio is mainly due to the influence of the extreme content of $\mathrm{Zn}$ 
(10.20 ppm) in Agroecosystem 3. This extreme increase of $\mathrm{Zn}$ is beyond all expectations since a drastic decrease was expected based on the higher calcium content obtained.

The exceptional high nutrients content in the black stony Pus Lu' um soil (rz LP) have been reported [21] to have the best chemical quality of nutrients as compared to the other stony soils of Yucatan. High contents of $\mathrm{OM}, \mathrm{N}-\mathrm{NO}_{3}, \mathrm{P}$ and micronutrients have been recorded. There are those who suggest that the application of fertilizers could be no functional [40].

The foregoing discussion should admit that shifting cultivation, based on slash and burn system, is a very complex ecosystem and it needs more scientific research to better understand and explain properly the soil fertility changes. Although Leoncio and Epitacio are Mayan farmers dedicated to manage their vegetation under shifting cultivation both have different agroecosystems with different forest ages and soils.

The soil fertility in those systems are very changeable in time and space depending on the distribution and quality of the vegetation. The kind of vegetation depends on the type of soil and, the amount of nutrients incorporated will also depend on the biomass and quality of the forest to be burned. It has been mentioned [41] that in the flat areas with red soils the trees tend to be larger and more widely spaced than those in the upper parts of the landscape with stony black soils.

On the other hand, mineralogy of soils needs to be considered for further studies since clay mineralogy is one of the most important indicators of soil quality and it is basic when considering the application and management of fertilizers as mentioned by Kogge Kome et al. [42]. By the way, although limestone rock is the underlying material of the studied area of Yucatan, the parent materials are rich in different types of clays such as: illite, kaolinite, smectite, montmorillonite, chlorite and powders carried by the wind from Africa. The soils in the upper part of the microrelief do not present secondary pedogenetic carbonates as those of the lower parts do [43].

\subsubsection{Correlation between Soil Attributes}

The intensity of the relationship between the soil attributes for both Leoncio and Epitacio systems, as reflected by the Correlation Index (r) and the Determination Coefficient $\left(\mathrm{R}^{2}\right)$, are being shown in Table 6.

Although the Correlation Coefficient between $\mathrm{OM}$ and $\mathrm{pH}$, in Leoncio's agroecosystems, was graded as Medium negative one $(r=-0.59)$ and the Determination Coefficient was low $\left(\mathrm{R}^{2}=0.35\right)$ the general trend was that the $\mathrm{pH}$ decreased while OM increased as it is shown in Figure 2. However, the opposite happened in Epitacio's Agroecosystems where the relationship between $\mathrm{OM}$ and $\mathrm{pH}$ ranked as Medium positive $r=0.45$ with $R^{2}=0.21$ and the $p H$ increased when OM increased too (Figure 3).

There was not found any good relationship between $\mathrm{OM}$ and $\mathrm{N}_{-} \mathrm{NO}_{3}$ in both Leoncio's and Epitacio's Agroecosystems and the Higher correlations between 
Table 6. Grade of relationship between Independent (x) and Dependent (y) variables as related to their corresponding Coefficients of Correlation $(r)$ and Determination $\left(R^{2}\right)$ in two shifting cultivation systems.

\begin{tabular}{|c|c|c|c|c|}
\hline Region & $\begin{array}{l}\text { Independent } \\
\text { variable }(x)\end{array}$ & $\begin{array}{l}\text { Dependent } \\
\text { variable }(y)\end{array}$ & $\mathbf{r}$ & $\mathbf{R}^{2}$ \\
\hline \multirow{9}{*}{ Leoncio Loría Chimal } & $\mathrm{OM}$ & $\mathrm{pH}$ & $-0.59(\mathrm{M})$ & 0.35 \\
\hline & $\mathrm{OM}$ & $\mathrm{N}-\mathrm{NO}_{3}$ & $-0.30(\mathrm{~L})$ & 0.09 \\
\hline & $\mathrm{OM}$ & $\mathrm{P}$ & $-0.84(\mathrm{H})$ & 0.72 \\
\hline & $\mathrm{OM}$ & $\mathrm{K}$ & $-0.64(\mathrm{M})$ & 0.41 \\
\hline & $\mathrm{OM}$ & $\mathrm{Zn}$ & $0.96(\mathrm{H})$ & 0.94 \\
\hline & $\mathrm{P}$ & $\mathrm{pH}$ & $0.65(\mathrm{M})$ & 0.43 \\
\hline & $\mathrm{K}$ & $\mathrm{pH}$ & $0.91(\mathrm{H})$ & 0.84 \\
\hline & $\mathrm{Ca}$ & $\mathrm{pH}$ & $-0.87(\mathrm{H})$ & 0.76 \\
\hline & $\mathrm{Zn}$ & $\mathrm{pH}$ & $-0.62(\mathrm{M})$ & 0.39 \\
\hline \multirow{9}{*}{ Epitacio Ku Puc } & $\mathrm{OM}$ & $\mathrm{pH}$ & $0.45(\mathrm{M})$ & 0.21 \\
\hline & $\mathrm{OM}$ & $\mathrm{N}-\mathrm{NO}_{3}$ & $0.22(\mathrm{~L})$ & 0.05 \\
\hline & $\mathrm{OM}$ & $\mathrm{P}$ & $0.44(\mathrm{M})$ & 0.20 \\
\hline & $\mathrm{OM}$ & $\mathrm{K}$ & $0.00(\mathrm{~L})$ & 0.00 \\
\hline & $\mathrm{OM}$ & $\mathrm{Zn}$ & $0.28(\mathrm{~L})$ & 0.08 \\
\hline & $\mathrm{P}$ & $\mathrm{pH}$ & $0.20(\mathrm{~L})$ & 0.042 \\
\hline & $\mathrm{K}$ & $\mathrm{pH}$ & $0.56(\mathrm{M})$ & 0.32 \\
\hline & $\mathrm{Ca}$ & $\mathrm{pH}$ & $0.70(\mathrm{M})$ & 0.50 \\
\hline & $\mathrm{Zn}$ & $\mathrm{pH}$ & $0.70(\mathrm{M})$ & 0.50 \\
\hline
\end{tabular}

Note: $\mathrm{H}=$ High, $\mathrm{M}=$ Medium, $\mathrm{L}=$ Low.

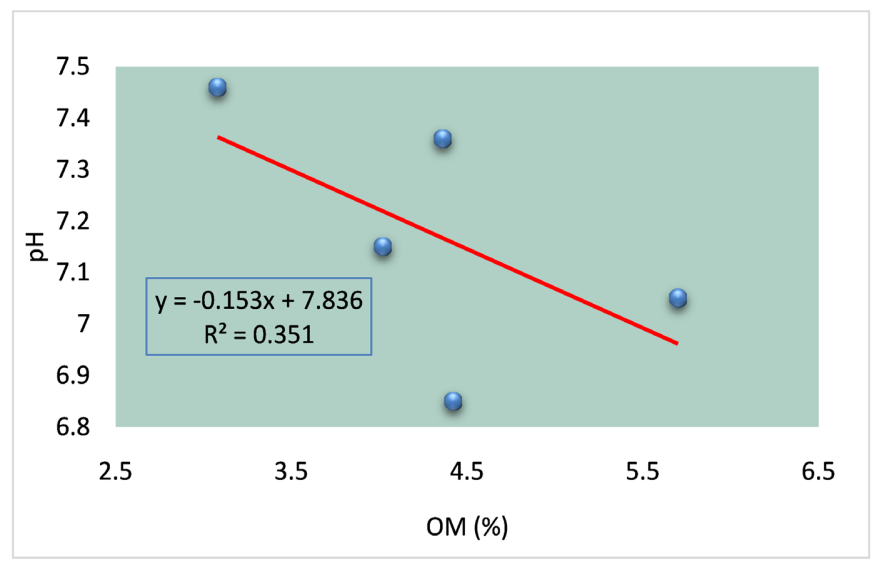

Figure 2. Correlation between Organic Matter and $\mathrm{pH}$ at $0-20 \mathrm{~cm}$ deep in soils of Leoncio's Agroecosystems. 
soil attributes corresponded to Leoncio with $\mathrm{OM}$ vs. $\mathrm{P}(\mathrm{r}=-0.84), \mathrm{OM}$ vs. $\mathrm{Zn}(\mathrm{r}$ $=0.90), \mathrm{K}$ vs. $\mathrm{pH}(\mathrm{r}=0.91)$ and Ca vs. $\mathrm{pH}(\mathrm{r}=-0.87)$.

In Figures 4-6 are shown some of the most important trend regression lines, the equations and the $\mathrm{R}^{2}$ of Leoncio's Agroecosystems characterized by having only red Cambisols. The available P decreased as OM increased (Figure 4) with a High negative $r=-0.84$ (Table 6 ) and high $\mathrm{R}^{2}=0.72$ which means that $\mathrm{P}$ contents depended $72 \%$ on OM changes in a negative relationship. In contrast, as it was shown in Table 6, $\mathrm{P}$ had a positive relationship with the $\mathrm{pH}$; the higher the $\mathrm{pH}$ the higher the $\mathrm{P}$ content in the soil. And, as it was discussed before, the highest $\mathrm{pH}$ 's were found in those Agroecosystems with SB cultivation as compared to those of old vegetation.

Although fire can induce to the mineralization of organic P [19] and therefore more available $\mathrm{P}$ can be released to the soil solution, the levels of $\mathrm{P}$ never reached sufficiency due to the negative influence of native carbonates. The same trend of $\mathrm{P}$, was for $\mathrm{K}$. The $\mathrm{OM}$ and $\mathrm{K}$ showed a negative relation (Table 6) but a High positive one with the $\mathrm{pH}$. The line trend, the equation and the High $\mathrm{R}^{2}=0.84$ shown in Figure 5 explain that the $\mathrm{pH}$ depended $84 \%$ on $\mathrm{K}$ contents in a positive relationship. This has to do with the alkaline effect of the K-carbonates-rich ash after burning.

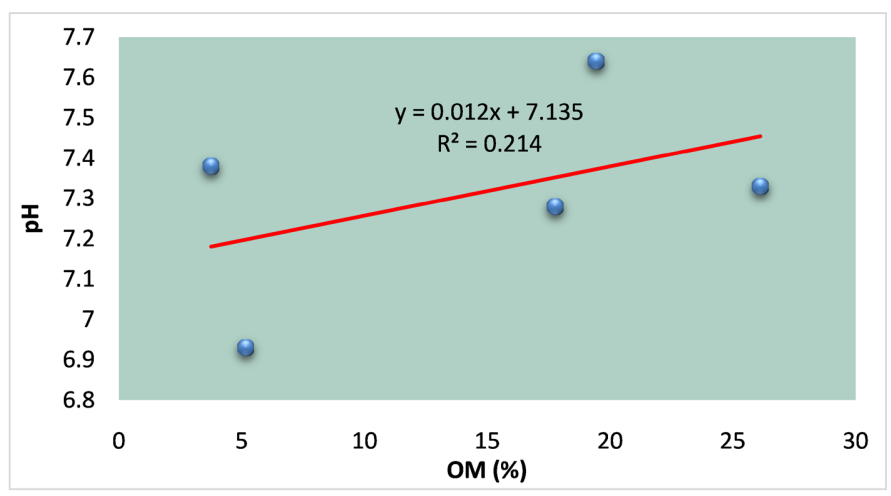

Figure 3. Correlation between Organic Matter and $\mathrm{pH}$ at $0-20 \mathrm{~cm}$ deep in soils of Epitacio's Agroecosystems.

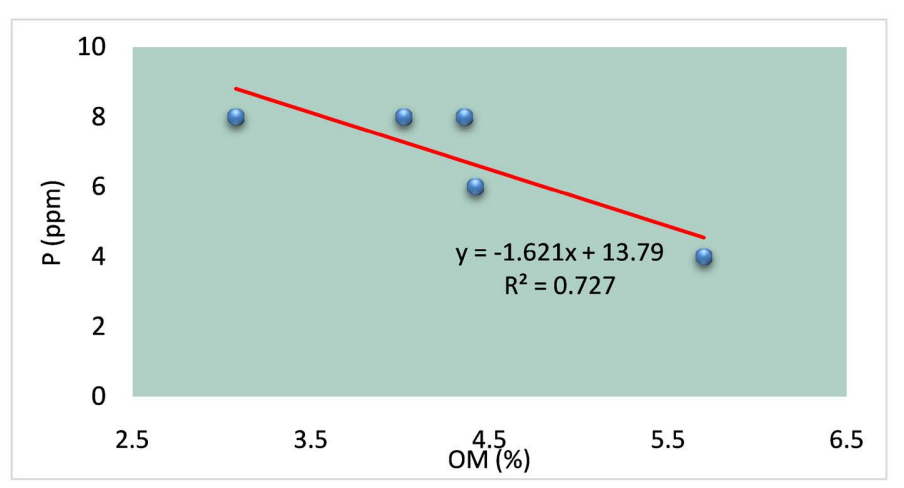

Figure 4. Correlation between Organic Matter (\%) and P (ppm) at $0-20 \mathrm{~cm}$ deep in soils of Leoncio's Agroecosystems. 


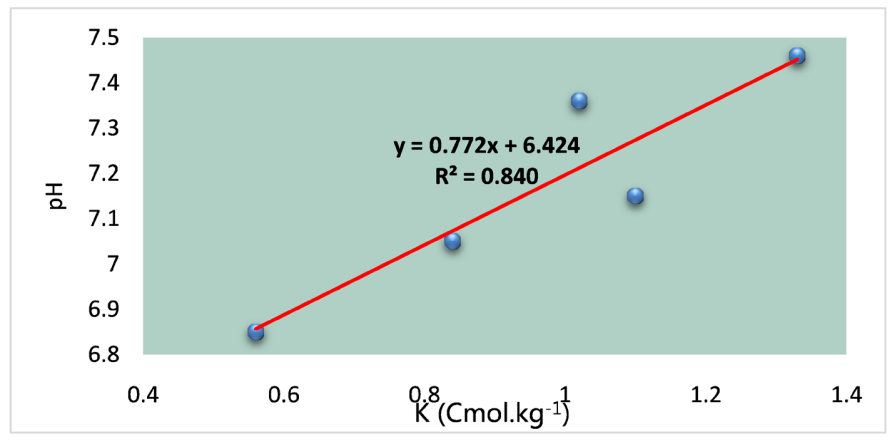

Figure 5. Correlation between exchangeable $\mathrm{K}$ and $\mathrm{pH}$ at $20 \mathrm{~cm}$ deep in soils of Leoncio's Agroecosystems under slash and burn cultivation.

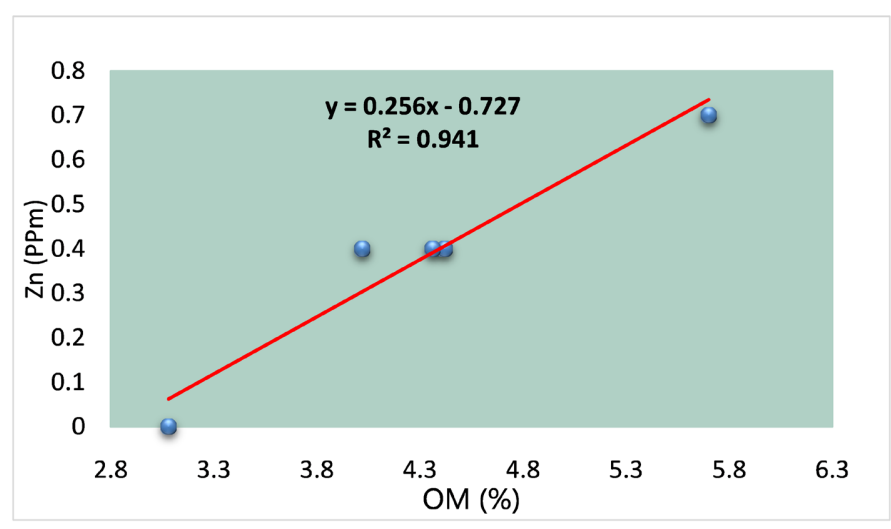

Figure 6. Correlation between $\mathrm{OM}(\%)$ and $\mathrm{Zn}(\mathrm{ppm})$ at $20 \mathrm{~cm}$ deep in soils of Leoncio's Agroecosystems under slash and burn cultivation.

Zn depended on the OM in a Very High positive way $\left(R^{2}=0.94\right)$ as it is being shown in Figure 6. In contrast, the Correlation Coefficient (Table 6) between $\mathrm{pH}$ vs. $\mathrm{Zn}$ was a Medium negative one $(\mathrm{r}=-0.62)$ with an $\mathrm{R}^{2}=0.39$. Despite the influence of $\mathrm{OM}$ on $\mathrm{Zn}$ contents, it seems that the influence of $\mathrm{pH}$ was greater than that of the OM. As $\mathrm{pH}$ increased more Hydroxides ions $\left(\mathrm{OH}^{-}\right)$are in the soil and therefore more $\mathrm{Zn}$ can be converted as $\mathrm{Zn}(\mathrm{OH})_{2}$, a non-available form of the nutrient.

\section{Conclusion}

Agroecosystems with long fallow periods, showed the lowest $\mathrm{pH}$ values. The other Agroecosystems, where slash and burn have been practiced, $\mathrm{pH}$ values tend to be higher due to the influence of ashes. All Agroecosystems showed High and Very High contents of $\mathrm{OM}$ although $\mathrm{N}-\mathrm{NO}_{3}$ and $\mathrm{P}$ was Low, except the Very High content of $\mathrm{N}^{-\mathrm{NO}_{3}}$ in the Agroecosystem 3 of Epitacio located in the rendzic Leptosol. In all Agroecosystems $\mathrm{K}$ and Ca were High whilst Mg was Medium. The overall average $\mathrm{Zn}$ content in Leoncio's was Lower (0.38 ppm) than Epitacio's ecosystem (2.76 ppm). Remarkable extreme overall average values for all soil attributes were found in Agroecosystem 3 of Epitacio in the rendzic Lepto- 
sol. There was not found any good relationship between $\mathrm{OM}$ and $\mathrm{N}-\mathrm{NO}_{3}$ in both Leoncio's and Epitacio's Agroecosystems but the Higher correlations between soil attributes corresponded only to Leoncio's. There was a general trend for nutrients to increase with the slash and burn system; however, it is compulsory to better explain each nutrient behavior and its interactions, including mineralogy, from a strictly scientific point of view.

\section{Acknowledgements}

This research work was launched thanks to the financial support of PRONATURAMexico as an environmental organization dedicated to promote the development of society in harmony with nature. Many thanks to the Mayan farmers: Leoncio Loria Chimal and Epitacio Ku Puc of the village of Nuevo Tezoco in Tizimin, Mexico located in the middle forest in eastern Yucatan.

\section{Conflicts of Interest}

The authors declare no conflicts of interest.

\section{References}

[1] Lanly, J.P. (1982) Tropical Forest Resources. FAO, Rome.

[2] Myers, N. (1993) Tropical Forests: The Main Deforestation Fronts. Environmental Conservation, 20, 9-16. https://doi.org/10.1017/S0376892900037176

[3] Hauck, F.W. (1974) Shifting Cultivation and Soil Conservation in Africa. FAO Soils Bull, 24, 1-4.

[4] Myyers, N. (1994) Tropical Deforestation: Rates and Patterns. In: Brown, K. and Pearce, D.W., Eds., The Causes of Tropical Deforestation, UCL Press, London, 388 p.

[5] Vargas, R.O., Rivera, O.D. and Mendoza, V.M. (1988) Sistemas de producción campesina y manejo de los ecosistemas en las riberas del río Güejar, Reserva Natural Integral La Macarena (Departamento del Meta, Colombia). Cuadernos de Agroindustria y Economía Rural, 22, 77-112.

[6] Bryant, D., Nielsen, D. and Tangley, L. (1997) The Last Frontier Forests. Ecosystems and Economies on the Edge. World Conservation Monitoring Centre and the World Wildlife Fund. 43 p.

[7] Myers, N. (1991) Tropical Forests: Present Status and Future Outlook. Climatic Change, 19, 3-32. https://doi.org/10.1007/BF00142209

[8] Food and Agriculture Organization (FAO) (1997) State of the World's Forests. FAO, Rome.

[9] Lara Ponce, E., Caso Barrera, L. and Aliphat Fernández, M. (2012) El Sistema Milpa Roza, Tumba y Quema de los Maya Itzá de San Andrés y San José, Petén Guatemala. Ra Ximhai, 8, 71-92. https://www.redalyc.org/pdf/461/46123333007.pdf https://doi.org/10.35197/rx.08.02.e.2012.06.el

[10] Pool Novelo, L. (1986) Experimentación en producción maicera bajo roza tumba quema en Yaxcabá, Yucatán, México, Tesis de Licenciatura. Universidad Autónoma Chapingo, Estado de México. 41-45.

[11] Rappaport, R. (1975) El flujo de energía en una sociedad agrícola. Biología y Cultura, 34, 379-391. 
[12] Arias Reyes, L.M. (1994) Análisis de las investigaciones del Programa Dinámica de la Milpa en Yucatán. Programa Dinámica de la Milpa 1979-1991. Revista de Geografía Agrícola, 173-178.

https://documen.site/download/analisis-de-las-investigaciones-del-programa-dina mica-de-la-milpa_pdf

[13] Remmers, G.G.A. and Ucán Ek, E. (1990) La roza-tumba-quema maya: Evaluación de un Sistema agroecológico tradicional bajo presiones de cambio tecnológico. Etnoecologia, 3, 1-8.

http://etnoecologia.uv.mx/Etnoecologica/Etnoecologica_vol3_n45/art_remm.htm

[14] Mariaca Méndez, R. (1988) Análisis estadístico de 6 años de cultivo continuo experimental de una milpa bajo roza-tumba-quema en Yucatán, México (1980-1986). Tesis de MC. Centro Botánica, Colegio de Postgraduados, Montecillo.

[15] Martínez, J., De las Heras, J. and Herranz, J. (1991) Impacto ecológico de los incendios forestales. Catedra de Botánica Forestal y Ecología y Medio Ambiente. Escuela Universidad Politécnica de Albacete. Universidad de Castilla La Mancha.

[16] González-Vila, F.J., Almendros, M.G., González-Pérez, J.A., Knicker, H., GonzálezVázquez, R., Hernández, Z., Piedra-Buena, A. and Rosa Arranz, J.M. (2009) Transformaciones de la materia orgánica del suelo por incendios naturales y calentamientos controlados en condiciones de laboratorio. Cátedra de divulgación de la ciencia, Valencia, 224-238. https://digital.csic.es/handle/10261/54782

[17] González, R. (2011) Impacto de los incendios forestales en la materia orgánica de los suelos. Tesis doctoral, Universidad de Sevilla, España, 25-40.

[18] Giardina, C.P., Sandford Jr., R.L. and Dockersmith, I.C. (2000) Changes in Soil Phosphorus and Nitrogen during Slash-and-Burn Clearing of a Dry Tropical Forest. Soil Science Society of America Journal, 64, 399-405.

https://www.researchgate.net/publication/255631189 https://doi.org/10.2136/sssaj2000.641399x

[19] Giardina, C.P., Sanford, R.L., Dockersmith, I.C. and Jaramillo, V.J. (2000) The Effects of Slash Burning on Ecosystem Nutrients during the Land Preparation Phase of Shifting Cultivation. Plant and Soil, 220, 247-260.

https://link.springer.com/article/10.1023/A:1004741125636 https://doi.org/10.1023/A:1004741125636

[20] Mataix-Solera, J., Cerda, A., Arcenegui, V., Jordán, A. and Zavala, L.M. (2011) Fire Effects on Soil Aggregation: A Review. Earth-Science Reviews, 109, 44-60.

https://www.sciencedirect.com/science/article/abs/pii/S0012825211001322 https://doi.org/10.1016/j.earscirev.2011.08.002

[21] García, E. (2004) Modificaciones al sistema de clasificación climática de Köpen (para adaptarlo a las condiciones de la República Mexicana). México. UNAM, Instituto de Geografía.

http://www.publicaciones.igg.unam.mx/index.php/ig/catalog/view/83/82/251-1

[22] Bautista, F., Palacio-Aponte G., Ortíz-Pérez, M., Bartllori-Sampedro, E. and Castillo-González, M. (2005) El origen y el manejo maya de las geoformas, suelos y aguas en la Península de Yucatán. In: Bautista, F. and Palacio, G., Eds., Caracterización y manejo de los suelos de la Península de Yucatán: Implicaciones Agropecuarias, Forestales y Ambientales, Universidad Autónoma de Campeche, Universidad Autónoma de Yucatán, Mérida, 21-32.

[23] Bautista, F., Maldonado, D. and Zinck, A. (2012) Clasificación maya de los suelos. Ciencia y Desarrollo, 260, 65-70.

https://www.cyd.conacyt.gob.mx/archivo/260/articulos/clasificacion-maya-suelos.html 
[24] Bautista, F. (2017) Suelos ambiente y algo más. Skiu. Ciudad de México. 140 p. https://actswithscience.com/Descargas/Libro\%20suelos,\%20ambiente\%20y\%20algo \%20m\%C3\%A1s.pdf

[25] Phytomonitor (2020) Archivo de análisis de fertilidad de suelos-2020 del laboratorio Phytomonitor. Calzada Aeropuerto N 7299-B. Colonia Bachigualato. Culiacán Sinaloa, México. CP. 80140.

[26] SEMARNAT (2002) Norma Oficial Mexicana NOM-021-RECNAT-2000, que establece las especificaciones de fertilidad, salinidad y clasificación de suelos, estudios, muestreo y análisis. Secretaria de Medio Ambiente y Recursos Naturales. Diario oficial. http://www.ordenjuridico.gob.mx/Documentos/Federal/wo69255.pdf

[27] Patel, J., Patel, N. and Shiyani, R. (2001) Coefficient of Variation in Field Experiments and Yardstick Thereof-An Empirical Study. Current Science, 81, 1163-1164. http://www.jstor.org/stable/24106429

[28] Pimentel, F. (1985) Curso de estatística experimental. Livraria Nobel S.A., São Paulo.

[29] Muñoz, J.D., Martínez, L.J. and Giraldo, R. (2006) Variabilidad espacial de propiedades edáficas y su relación con el rendimiento en un cultivo de papa (Solanum tuberosum L.). Agronomía-colombiana, 24, 355-366.

https://www.redalyc.org/articulo.oa?id=180316239020

[30] Ortiz Villanueva, B. (1977) Fertilidad de suelos. Universidad Autónoma de Chapingo, Chapingo.

[31] Etiégni, L. and Campbell, A.G. (1991) Physical and Chemical Characteristics of Wood Ash. Bioresource Technology, 37, 173-178.

https://www.sciencedirect.com/science/article/abs/pii/096085249190207Z https://doi.org/10.1016/0960-8524(91)90207-Z

[32] Medina-Méndez, J., Volke-Haller, V., Galvis-Spínola, A., Cortés-Flores, J.I. and Santiago-Cruz, M.J. (2017) Incremento de la materia orgánica del suelo y rendimiento de mango en Luvisoles, Campeche, México. Agronomía Mesoamericana, 28, 499-508. https://www.scielo.sa.cr/pdf/am/v28n2/43750618014.pdf https://doi.org/10.15517/ma.v28i2.22236

[33] Ford, D., Palmer, A. and White, W. (1988) Landform Development; Karst. In: Back, W., Rosenshein, J.S. and Seaber, P.R., Eds., Hydrogeology (The Geology of North America, Volume O-2), Geological Society of America, Boulder, 576.

[34] Celaya-Michel, H. and Castellanos-Villegas, A.E. (2011) Mineralización del nitrógeno en el suelo de Zonas áridas y semiáridas. Terra Latinoamericana, 29, 343-356. https://www.redalyc.org/pdf/573/57321283013.pdf

[35] Tisdale, S.L. and Nelson, W.L. (1982) Fertilidad de los suelos y fertilizantes. Ed. UTHEA, México, 760 p.

[36] Bautista-Zúñiga, F., Jiménez-Osornio, J., Navarro-Alberto, J., Manu, A. and Lozano, R. (2003) Microrelieve y color del suelo como propiedades de diagnóstico en Leptosoles cársticos. Terra Latinoamericana, 21, 1-11. https://www.redalyc.org/pdf/573/57321101.pdf

[37] Castellanos, J.Z., Uvalle-Bueno, J.X. and Aguilar-Santelises, A. (2000) Manual de interpretación de análisis de suelos y aguas. Segunda Edición, Serie: Colección INCAPA, Instituto de Capacitación para la Productividad Agrícola, 186-212.

[38] Adams, M. (1995) Fundamentos de química de suelos. Universidad Central de Venezuela Consejo de Desarrollo Científico y Humanismo. Caracas, Venezuela. 27-46.

[39] Ramírez-Silva, J.H., Aguilar-Duarte, Y. and Cano-González, A. (2015) Contenido de 
Zinc en suelos y plantas de maíz comercial el Quintana Roo, México. Memoria de la XXVII Reunión Científica Tecnológica, Forestal y Agropecuaria Tabasco 2015. IV Simposio Internacional en Producción Agroalimentaria Tropical. 29-32.

[40] Pool, L. and Hernández, E.X. (1995) Bases de la experimentación agrícola bajo roza, tumba y quema: El caso de la milpa. In: Hernández, E., Bello, E. and Levy, S., Eds., La milpa en Yucatán: Un sistema de producción agrícola tradicional, Tomo 2, Colegio de Postgraduados, El Colegio de Postgraduados, Montecillo, 313-337.

[41] Trejo-Torres, J.C. (2014) Vegetación y Paisaje del Puuc de Yucatán. Reporte final del proyecto "Difusión Ambiental en la Reserva Biocultural Estatal Puuc". Kaxil Kiuic A.C. and Programa de Pequeñas Donaciones-FMAM-México-PNUD, Mérida, $54 \mathrm{p}$.

http://www.kaxilkiuic.org.mx/wp-content/uploads/2020/07/Vegetacion_y_Paisaje_e n_el_Puuc_Trejo_FINAL-reducido_compressed.pdf

[42] Kogge Kome, G., Kogge Enang, R., Oben Tabi, F. and Kfuban Yerima, B.P. (2019) Influence of Clay Minerals on Some Soil Fertility Attributes: A Review. Open Journal of Soil Science, 9, 155-188. https://doi.org/10.4236/ojss.2019.99010

[43] Krasilnikov, P., Gutiérrez-Castorena, M.C., Ahrens, R.J., Cruz-Gaistardo, C.O., Sergey, S. and Solleiro-Rebolledo, E. (2013) The Soils of Mexico. World Soils Book Series, Springer, New York. https://doi.org/10.1007/978-94-007-5660-1 